\title{
Rethinking experimental music within music education: Thoughts and feelings after a voyage through the Project INsono
}

\section{Repensar la música experimental dentro de la educación musical: pensamientos y sensaciones después de un viaje a través del Proyecto INsono}

\author{
Ana Luísa Veloso \\ anaveloso@ese.ipp-pt \\ CIPEM \\ College of Education \\ Porto Polytechnic \\ Porto, Portugal \\ ORCID: http://orcid.org/0000-0001-8078-0788
}

doi: 10.7203/LEEME.46.17409

Recibido: 17-05-2020 Aceptado: 30-07-2020. Contacto y correspondencia: Ana Luísa Veloso, CIPEM/INET-md, Politécnico do Porto, Rua Dr. Roberto Frias, 602. 4200-465, Porto. Portugal.

\begin{abstract}
This paper tells the story of INsono, an interactive sound installation and workshop created by a group of musicians for the 6th edition of the Big Bang in Lisbon, Portugal. To tell this story I will present my findings throughout a narrative that evolves through the analysis and interpretations of interviews with the musicians and the curator of the Big Bang Lisbon, field notes taken during the creation and the presentation of INsono, and group interviews with children about their lived experiences during the workshop. Describing the process that led to the creation of the final sound installation, I will explore, on one side, what were the main concerns and ideas of the musicians and the curator of the festival in what regards concepts such as education, childhood, music, and art, and, on the other, the perspectives of children that participated in the workshop on their experiences of INsono. This will, hopefully, lead us to a discussion where we might rethink the potentialities of experimental music in both formal and non-formal contexts of learning; moreover, it might lead us also to look at the dynamics, strategies and tools that are used in non-formal contexts as a source of inspiration to reflect on pedagogical approaches in the classroom that might enrich the musical and artistic experiences of children.
\end{abstract}

Key words: Experimental music; music education; formal and non-formal contexts of learning; creativity.

\section{Resumen}

Este artículo describe la experiencia en INsono, una instalación sonora interactiva y un taller creado por un grupo de músicos para la $6^{a}$ edición del Festival Big Bang en Lisboa, Portugal. Se presentan los hallazgos a lo largo de una narración que se desarrolla a través del análisis e interpretaciones de entrevistas con los músicos y la comisaria del Festival, las notas de campo tomadas durante la creación y la presentación de INsono así como entrevistas grupales con los niños sobre sus experiencias vividas durante el taller. En la descripción del proceso que llevó a la creación de la instalación sonora final, se exploró por una parte las principales preocupaciones e ideas de los músicos y la comisaria del Festival, incidiendo en conceptos como la educación, la infancia, la música y el arte; por otra parte, se ampliaron con las perspectivas de los niños que participaron en el taller acerca de su experiencia con INsono. Es de esperar que las conclusiones sugieran un debate en el que podamos repensar las potencialidades de la música experimental en contextos de aprendizaje tanto formales como no formales; además, podría conducir también al examen de las dinámicas, estrategias y herramientas que se utilizan en contextos no formales, siendo estos elementos que ayuden a la reflexión sobre enfoques pedagógicos en el aula, enriqueciendo las experiencias musicales y artísticas de los niños.

Palabras clave: Música experimental; educación musical; contextos de aprendizaje formales y no formales; creatividad.

@ Ana Luísa Veloso. The content of this article is the sole responsibility of the authors. The Revista Electrónica de LEEME and Universitat de València are not liable for any legal actions that may arise involving the article's content. Revista Electrónica de LEEME - Lista Electrónica Europea de Música en la Educación-. http://ojs.uv.es/index/php/LEEME/index ISSN: 1575-9563. Editores: Universidad de Valencia y Jesús Tejada. Visibilidad de esta revista: SCOPUS, Emerging Sources Citation Index (Clarivate), EBSCO, CINDOC (CSIC), Citefactor, COPAC, Dialnet, DICE (CSIC), DOAJ, e-revistas (CSIC), EBSCO Premier, ERIH+, Gale Cengage Learning, INRECS, IRESIE, LATINDEX, MIAR, OCLC Worldcat, RESH, REDIB, RILM Core Journals, SUDOC, ULRICHS. Esta revista es de acceso libre mediante licencia Creative Commons 4.0 CC by. Política de archivado: etiqueta verde SHERPA-ROMEO 


\title{
1. A first glimpse - Introducing the Project INsono
}

\begin{abstract}
A small boy aged around seven opens his eyes deeply, struck with surprise. He has a big pair of red headphones in his ears. On one side of the headphones is hanging a string guitar that the little boy rubs with a cello bow. He opens a big smile and tries it again and again. He then gives the headphones to a friend, encouraging him to try. The two boys look to each other making a big smile, as if they were keepers of a secret that only they are aware of. At that moment they listen to other sounds crossing the room, and quickly join the rest of the group that is exploring INsono with them. They are attentive to everything and allow themselves to be guided by the musicians that are leading the workshop/sound route. The whole group is in silence, with eyes and ears wide open. While interacting with the sound installation they listen to sounds, feel them in their bodies and touch the sounding materials. They get close and apart from each device, they go in and out; they lay down in a bed of wood where they feel several sound vibrations; they touch smoothly on a mirror that is connected to an iPad using their fingertips, and their faces reveal the astonishment listening to the sounds. They crouch up, sit and lay down while interacting with sounds, as if talking to them, dialoguing with them, in a multisensory experience. To me, it seems that they are immersed in an "ocean of sound" 1 , as if living for fifty minutes inside music and sound, and inside the materials that produce them (Field notes, November 23, 2015).
\end{abstract}

The field notes written above were taken during the first presentation of INsono at Centro Cultural de Belém (CCB), in Lisbon. INsono is a sound installation/collective musical instrument, as well as a sensory journey/experience that was created following an invitation made in September 2014 by Madalena Wallenstein, the coordinator of the educational service of Centro Cultural de Belém, to Sonoscopia ${ }^{2}$. The challenge was to create a sound installation for Big Bang, a music festival for young audiences that:

- Aims to present the richness of music in an imaginative and adventurous way, accessible to children.

- Exists in an awfully close co-operation between performance and education.

- Exists now in a partnership between fifteen European cities: Athens, Québec, Rennes, Reykjavik, Enschede, Dublin, Seville, Ottawa, Rouen, Lille, Tallinn, Gent, Brussels, Antwerp and Lisbon.

Madalena's invitation was made directly to Henrique, one of the founding members of Sonoscopia. Thus, the first step of Henrique was to create a team of musicians/educators that could develop the sound installation to the festival. From this group, two musicians also belonged to Sonoscopia (Gustavo and Tiago) and one of them did not, although he works regularly with the association (Rodrigo). I joined the team soon after the invitation, in a double role of researcher and educator. I participated in the entire process that led to the creation of INsono, from the first ideas and discussions at Sonoscopia about what we were supposed to do, to the final presentation of the sound installation. This gave me the possibility of reflecting on INsono and its purposes from a double perspective: on one side I was with the musicians all the

\footnotetext{
${ }^{1}$ Tittle of a book written by David Toop (1995).

2 A Portuguese association/platform dedicated to the creation, production and promotion of artistic and educational projects, primarily focused in the area of experimental music and sound research.
}

@ Ana Luísa Veloso. The content of this article is the sole responsibility of the authors. The Revista Electrónica de LEEME and Universitat de València are not liable for any legal actions that may arise involving the article's content. Revista Electrónica de LEEME - Lista Electrónica Europea de Música en la Educaciónhttp://ojs.uv.es/index/php/LEEME/index ISSN: 1575-9563. Editores: Universidad de Valencia y Jesús Tejada. Visibilidad de esta revista: SCOPUS, Emerging Sources Citation Index (Clarivate), EBSCO, CINDOC (CSIC), Citefactor, COPAC, Dialnet, DICE (CSIC), DOAJ, e-revistas (CSIC), EBSCO Premier, ERIH+, Gale Cengage Learning, INRECS, IRESIE, LATINDEX, MIAR, OCLC Worldcat, RESH, REDIB, RILM Core Journals, SUDOC, ULRICHS. Esta revista es de acceso libre mediante licencia Creative Commons 4.0 CC by. Política de archivado: etiqueta verde SHERPA-ROMEO 
time, participating in the dialogues, listening carefully, and sharing my visions. This brought me new insights that were of great help when I was leading the interviews, writing my field notes, or reflecting. On the other side, I was not responsible for the creation of the installation and so, whenever I felt it was needed, I could step aside and reflect on my own, going back again and again to the data, searching for meaningful literature, and writing my own thoughts and ideas, in a process of constant triangulation between the different data sets, the literature, and my own feelings and perspectives about the entire journey.

\subsection{The use of narrative in this text}

In my pathway as a teacher, musician and researcher, I have always looked for methods that would allow me to present research in a way that could resemble, as much as possible, the subjectivities and myriad voices that emerge on contexts where human beings interact. Slowly, I found that narrative and narrative analysis seemed to open a vast space to the presence of the multiple perspectives and understandings that I found in my research endeavors. I turned to the writings of Bruner $(1990,1996)$, and eventually I came to realize that my deep interest in personal stories was not totally unfounded. In his texts, Bruner made clear that narrative, distinguished for its temporal, procedural, situated, and personal character, is a crucial process in the ways human beings build and shape human experience and create meanings for their worlds. Going back and forth from Bruner to those in the field of Music Education that acknowledged his thinking (Barrett \& Stauffer, 2009, 2012; Bowman, 2006, 2009; Mota, 2020) I understood that the "narrative turn" mentioned in their texts allowed researchers to "recover concreteness, particularity, individuality, and situatedness" (Bowman, 2006, p.9). Through this way I began to think about research as a co-construction of shared experiences, as a collaborative endeavor for meaning making where we, the researchers,

become part of participants' lives and they part of ours [....]. We are relational inquirers, attentive to the intersubjective, relational, embedded spaces in which lives are lived out. We do not stand metaphorically outside the inquiry but are part of the phenomenon under study (Clandinin, 2013, p.24).

\section{Data Collection and Analysis}

Data about the entire process that led to the construction of INsono, and about the perspectives of musicians and Madalena Wallenstein, were collected through participant observation, field notes, photos, and interviews. Data about children's perspectives on INsono were collected mainly through non-interventionist observation, field notes, group interviews, and photos. All data were collected during three main periods:

- From June 2015 to November 2015: Data related to the process of construction of INsono Participant observation, field notes, group interview with musicians, photos.

@ Ana Luísa Veloso. The content of this article is the sole responsibility of the authors. The Revista Electrónica de LEEME and Universitat de València are not liable for any legal actions that may arise involving the article's content. Revista Electrónica de LEEME - Lista Electrónica Europea de Música en la Educación-, http://ojs.uv.es/index/php/LEEME/index ISSN: 1575-9563. Editores: Universidad de Valencia y Jesús Tejada. Visibilidad de esta revista: SCOPUS, Emerging Sources Citation Index (Clarivate), EBSCO, CINDOC (CSIC), Citefactor, COPAC, Dialnet, DICE (CSIC), DOAJ, e-revistas (CSIC), EBSCO Premier, ERIH+, Gale Cengage Learning, INRECS, IRESIE, LATINDEX, MIAR, OCLC Worldcat, RESH, REDIB, RILM Core Journals, SUDOC, ULRICHS. Esta revista es de acceso libre mediante licencia Creative Commons 4.0 CC by. Política de archivado: etiqueta verde SHERPA-ROMEO. 
- In November 2015, during the debut of INsono at the Portuguese edition of the Big Bang Festival: Interview with Madalena Wallenstein, non-interventionist observation when children were visiting and exploring INsono.

- In February 2017, during a second presentation of INsono at Fábrica das Artes (FDA), (Arts' Factory, AF) the name given to the educational service of CCB: Group interviews with children participating in INsono, non-interventionist observation when children were visiting and exploring INsono, photos.

The gap of two years between the two main periods of data collection are due to two reasons: First, it seemed to me that observing participants interacting with INsono for only two days during the Big Bang festival (2015) was not enough. Second, and most importantly, despite all the best efforts of the FDA's staff, it was impossible to schedule the group interviews with children, something that was extremely important for the present study. When Madalena Wallenstein invited Sonoscopia to render a second presentation at FDA for one month February 2017 - it was much easier to arrange all the necessary details for the group interviews with children, and for a second phase of non-interventionist observation.

After the transcription of the interview with Madalena Wallenstein, we had several informal talks (both in 2015 and 2017) to clarify her positions in relation to the topics covered in the interview. The same happened with the musicians, who were interviewed first as a group in October 2015, and with whom I also had several long informal talks, individually or in group, that allowed me to better analyze and deepen the themes explored in their group interview.

Group interviews with children took place from February 14 to February 16, during a second presentation of INsono at FDA. Three groups of children, with ages ranging from 5 to 8 years old, were observed before the interview. Each group belonged to a different class from two different schools in Lisbon, in a total of 40 children, and with each group being composed by 12 to 15 children. These two schools have a partnership with the FDA, as well as with other institutions in Lisbon that promote cultural and artistic activities. Therefore, these are schools whose principals and teachers are especially attentive to the importance of the arts in children's development, promoting activities inside and outside school, related to music, theater, plastic arts, or philosophy, among others.

All the process of interviewing was previously agreed with Madalena Wallenstein, all the staff from the educational service, the musicians, and children's teachers. Thus, immediately after leaving the room where INsono was being explored, each group was divided in two: One of the groups would stay with me for the interview, while the other would stay with their teacher having the morning /afternoon snack (depending if the visit had taken place in the morning or in the afternoon). Each interview lasted for about 20 minutes, with groups from each class alternating between "group interview" and "snack".

@ Ana Luísa Veloso. The content of this article is the sole responsibility of the authors. The Revista Electrónica de LEEME and Universitat de València are not liable for any legal actions that may arise involving the article's content. Revista Electrónica de LEEME - Lista Electrónica Europea de Música en la Educación-. http://ojs.uv.es/index/php/LEEME/index ISSN: 1575-9563. Editores: Universidad de Valencia y Jesús Tejada. Visibilidad de esta revista: SCOPUS, Emerging Sources Citation Index (Clarivate), EBSCO, CINDOC (CSIC), Citefactor, COPAC, Dialnet, DICE (CSIC), DOAJ, e-revistas (CSIC), EBSCO Premier, ERIH+, Gale Cengage Learning, INRECS, IRESIE, LATINDEX, MIAR, OCLC Worldcat, RESH, REDIB, RILM Core Journals, SUDOC, ULRICHS. Esta revista es de acceso libre mediante licencia Creative Commons 4.0 CC by. Política de archivado: etiqueta verde SHERPA-ROMEO. 
Previously to the interviews, each teacher talked to the parents of their children's class to obtain consent for the audio recordings. At that time, it was also agreed that the name of the schools would stay anonymous, and children's names, when used for research purposes, would be fictitious. However, the names of the musicians and of the director of FDA (Madalena Wallenstein) are the real ones. This was agreed in a conversation we had prior to the beginning of the investigation. Moreover, in the end of the writing process, the article was given back to the musicians and to Madalena, so that they could have the opportunity to read it and to give their feedback about what had been written.

Data collected were analyzed in a process that evolved from coding, with each data source being coded separately, to the development of categories and themes (Saldaña, 2009). In order to obtain credibility, data analysis from the interviews, group interviews to children and field notes were continuously triangulated, so that analysis and interpretation could be open to the participants' plurality of perspectives and meanings (Flick, 2014; Stake, 2008). As already observed in a previous section, the themes that emerged from the process of analysis, were explored in a narrative way, that was used, in the present article, not only as an organizing principle, but also to give voice to the different actors participating in this journey.

\subsection{The birth of INsono}

Going back a few months, I suddenly remember the first time I interviewed Henrique, the musician that conceived INsono. Back then he explained me that when Madalena Wallenstein contacted him and Sonoscopia, she specifically asked for a sound installation that "could be explored by children as a meaningful artistic experience". Henrique, recalling that moment, explained that he immediately thought about a structure that could resemble the idea of "what it would be like to be inside a musical instrument". And in fact, as we may read in his personal notes:

Since I can recall, I wonder what it would be like to be inside a musical instrument! The interior and innermost spaces of instruments are mysterious/inscrutable/mystical places, inaccessible to us.

I remember, when I was still a child, peeking inside a cello or a piano, trying to understand its secrets...

I longed to go beyond that which my eyes could see, and my ears could hear!

So, I would close my eyes and climb aboard this mysterious world. I would imagine its smell, its textures, its sounds...

INsono springs to life from this memory, and the first efforts of this group of musicians to materialize it are well documented in Henrique's drawings on his personal notes (Figures 1, 2 and 3): 
ISSN:1575-9563
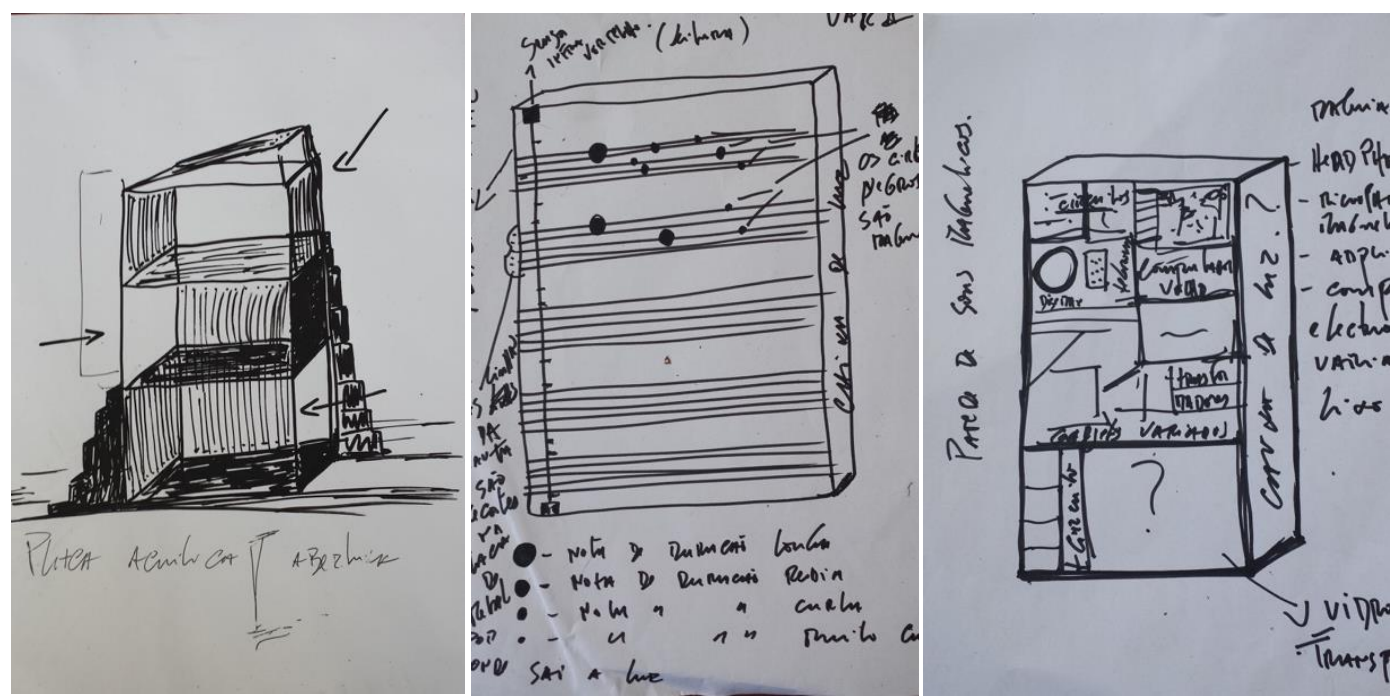

Figures 1, 2 and 3. First ideas for the construction of INsono

These drawings illustrate a process that I could observe closely: the musicians, working together, developed a powerful collaborative experience, exploring materials, sounding objects and digital devices, experimenting several approaches in what regards working with space and sound. After two months of intense work, INsono, a large wood structure divided in five compartments, "five little houses" as I used to call them, finally came into being (Figure 4).

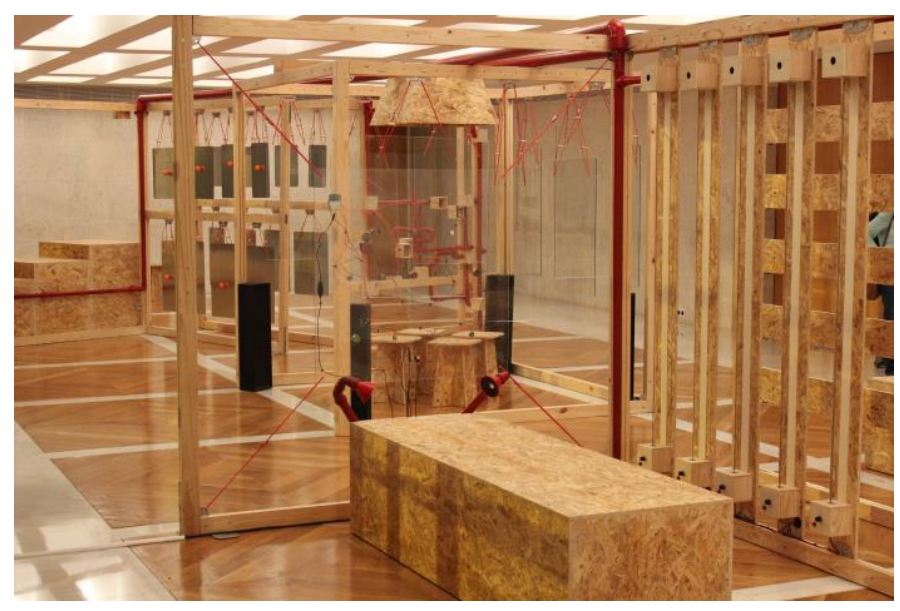

Figure 4. INsono - "Five little houses"

@ Ana Luísa Veloso. The content of this article is the sole responsibility of the authors. The Revista Electrónica de LEEME and Universitat de València are not liable for any legal actions that may arise involving the article's content. Revista Electrónica de LEEME - Lista Electrónica Europea de Música en la Educación-. http://ojs.uv.es/index/php/LEEME/index ISSN: 1575-9563. Editores: Universidad de Valencia y Jesús Tejada. Visibilidad de esta revista: SCOPUS, Emerging Sources Citation Index (Clarivate), EBSCO, CINDOC (CSIC), Citefactor, COPAC, Dialnet, DICE (CSIC), DOAJ, e-revistas (CSIC), EBSCO Premier, ERIH+, Gale Cengage Learning, INRECS, IRESIE, LATINDEX, MIAR, OCLC Worldcat, RESH, REDIB, RILM Core Journals, SUDOC, ULRICHS. Esta revista es de acceso libre mediante licencia Creative Commons 4.0 CC by. Política de archivado: etiqueta verde SHERPA-ROMEO. 


\subsection{Engaging children in meaningful musical experiences through INsono}

INsono is a space where children and grown-ups can experience sound in multiple and interactive ways, while having also the opportunity to listen to the entire soundscape of the room (https://vimeo.com/161972809). For Henrique, and for the other musicians from Sonoscopia, the big challenge was to create a structure that could be explored freely and safely by children, encouraging them to create significant soundscapes and music compositions collectively, and that could act as a space for meaningful listening, sparking their curiosity and imagination.

Defying concepts of what is so many times considered as musical activities for children, they concentrated their thoughts in two main points: The first one was related to the music making possibilities that could emerge from children's explorations while participating in INsono. The second one concerned the distribution on space of the five parts of the installation how the sound produced in the different areas of the room could contribute to an interesting musical result - and what strategies they could use to communicate with children, and to invite them to interact with the materials and with each other.

\subsubsection{Rethinking the meanings of music and "music for children"}

The first aspect of this perspective asks for a special attention and a careful consideration on the meanings of 'music' and 'music for children' (including listening, performing, and creating). In fact, during the interview, and also during informal conversations, this group of musicians, openly acknowledging the thoughts introduced by Cage (1994) stated clearly that, for them, music is perceived as a form of expression and communication opened to all sounds, including noise. Gustavo, for example, was highly amazed with the amount of people that still consider that music can only be composed with sounds of musical instruments:

\footnotetext{
It's still strange to me how after a hundred and so years after the collapse of the tonal system, it's still weird for most people to make music with heaters, or with the rain, or with... a fridge... It remains something that is considered wrong, or strange. (...) I mean, I think a piano sound is as normal as the sound of the rain. And making music with these sounds is just as normal as music that was made historically with the so-called conventional instruments. And that is also very important to note here at INsono, because children sometimes have contact with ways of listening and ways of experimenting with sound sources other than.... That before they probably did not see as musical...
}

This idea is intimately related with the domain of experimental music, in which these musicians develop their artistic and educational works. Experimental music is defined here as a musical field that, a) moves away from the western classical tradition and the composers included on the avant-garde music that followed, in many ways, this same tradition (Nyman, 1999); b) by moving away from the western classical tradition opens up to other music's such as free jazz, experimental electronic music or noise (Holmes, 2008); and c) unfolds through a

@ Ana Luísa Veloso. The content of this article is the sole responsibility of the authors. The Revista Electrónica de LEEME and Universitat de València are not liable for any legal actions that may arise involving the article's content. Revista Electrónica de LEEME - Lista Electrónica Europea de Música en la Educación-. http://ojs.uv.es/index/php/LEEME/index ISSN: 1575-9563. Editores: Universidad de Valencia y Jesús Tejada. Visibilidad de esta revista: SCOPUS, Emerging Sources Citation Index (Clarivate), EBSCO, CINDOC (CSIC), Citefactor, COPAC, Dialnet, DICE (CSIC), DOAJ, e-revistas (CSIC), EBSCO Premier, ERIH+, Gale Cengage Learning, INRECS, IRESIE, LATINDEX, MIAR, OCLC Worldcat, RESH, REDIB, RILM Core Journals, SUDOC, ULRICHS. Esta revista es de acceso libre mediante licencia Creative Commons 4.0 CC by. Política de archivado: etiqueta verde SHERPA-ROMEO. 
process of investigating, a research endeavor, a constant quest for what is new and unique (Tenney, 2015).

This definition involves not only an attitude of openness and letting go of control towards much of what happens musically in a performance, but also to the search for new sounds and sound sources, that cause, frequently, big curiosity and surprise. The musicians that created INsono were not unaware of this issue, as can be observed in the words of Henrique:

We wanted that INsono could be a space open to diverse learning processes and discoveries. One of our aims was that children could explore a universe that was relatively unknown to them. We wanted that participants could listen, create, and interact with each other departing from objects that are commonly used in their daily lives, but not with a musical intention ...That's why this was also called INsono, right?

To this, Rodrigo added that,

One of our main concerns was that the sounding objects that are part of INsono could really act as a... surprise, catching children's attention and sparking their curiosity. Ana: So, you chose the materials for the creation of INsono with that intention in mind?

R: Yes, of course... To create the effect of surprise... For example, the springs we used produce a sound that maybe children are not used to listen... They might know what a spring is, but now, they have the opportunity to look at it as sound material that might be used to create music.

Moreover, it also involves a position that goes against the idea of what is commonly understood as "music for children". During the group interview Henrique clearly stated: "For me there is no such thing as music for children. It's as simple as that". To which Gustavo added:

I think that, especially for a child, it is just as normal to listen to the sounds of a common object, I mean of any object that produces sounds, than it is of a violin. Because they are not yet formatted to think that music is made with a certain type of musical instruments, with certain codes...

The idea advocated by Henrique and Gustavo was also clearly present in Madalena's discourse:

\begin{abstract}
The question for me, Ana, is why there is such a deep separation in our discourses, when it comes to think about art for childhood. I mean what distinguishes a project for childhood, a thing for childhood, from a project for adults? Why is there such a division? This is truly amazing for me... Why is it that in our conceptual, cognitive frameworks... We are... we continually slip into this thing that there are divisions, that there are stages of development, that there are things for adults, and specific things for children... This is the my first big question.
\end{abstract}

Overall, this view points to a different conception not only of music but also of education. A conception linked to experimental music and to its educational potential (Tinkle, 2015; Woods, 2019;), a more, open, "democratic" understanding not only of what is considered as "music for children", but even more specifically, of what counts as musical material, and that, as Hill (2018) reminds us, subverts the norms that for centuries, have defined what is and 
what is not musical, emancipating "sound from narrow definitions of 'music' and limited conceptions of what makes music 'good' or 'right"' (p.50).

However, experimental music and its inclusion in music education is far from being a consensual idea. Reflecting on the creative music movement of the 1960s and 1970s, that represents a major tenet in what respects approaching experimental music in the classroom, Green (2008) comments that this movement fell short to gain children's interests and participation. According to the author this happened because the musical materials and ideas that were explored in the classroom were unfamiliar to children and because the compositional practices that were valued were based on the classical music tradition and not on "real-world composing practices" (2008, p.11), that children know and use in their daily lives. This aspect led to what Green named as "alienation", meaning a detachment from both the inter-sonic and delineated meanings of the musical materials used within the field of experimental music. Finney, on the other side, while also acknowledging the critique that was and is made to the creative movement, both within the fields of philosophy and sociology (2011a) nevertheless calls our attention to the example of John Paynter, whom, as one of the exponents of this movement, developed his perspective through a new epistemology based on "a plurality of knowledge forms, the recognition that there were different ways of knowing, different ways of making meaning and significance, different kinds of truth" (Finney, 2011b, p.18). This legacy thrives until our days and still inspires teachers all over the world. In fact, and albeit all the criticism that was later made to this movement, the "artist-teacher" and the child as a creative being, as someone that creates meaning for the world through the medium of sounds and music, prevails until today as an artistic and educational idea of paramount importance.

\subsection{Interacting with INsono: affordances and pedagogical strategies}

The other aspect mentioned by musicians points to a perspective of education as an open process, where there is not a right and wrong way of doing things, and that is largely stimulated by the means an activity is introduced, and the affordances (in terms of musical and personal interactions) prompted by that same musical activity:

\footnotetext{
Gustavo: This is a real situation where... None of us had the intention of trying to show what was right or wrong, for whoever went to see INsono, see and hear INsono. Uh, and... And I think that's one of INsono's most pedagogical experiences...

Henrique: Right.

Gustavo: Our intention was that each child could leave the experience with their own thoughts and feelings, depending of course on the ways they had related with the several "components" of INsono. At least that was our goal, we were there to share what we had done but not from a perspective of: "O.K, now you do this in this way, and you do that in that way". Hum... Our goal was that each participant could create her own images and, ideas...
}

The concept of affordance is embedded within the ecological approach to perception (Gibson, 1979; Reybrouck, 2012; Windsor \& Bézenac, 2012) and points to the idea that meanings are created from the interaction between subjects and their environment. In musical 
terms this approach prioritizes "relational qualities in music perception and action, highlighting the active nature of musical participation and interpretation: Those aspects of musical behavior that result from interactions between musicians, instruments, environments and listeners" (Windsor \& Bézenac, 2012, p.103). In INsono, we find many examples of this: The small red balls that invited children to push them and play the gongs; the small corridors between the structures that encouraged them to cross over and listen. The beds that vibrated with the sound of the springs and that welcomed them to lie down and feel the sound all over their bodies. The small shelters that attracted them to come in and out, alternating between sound and silence, something made possible by the movement sensors that existed in this part of INsono. In this sense, we may say that, in this specific project, the concept of affordance can be understood as a potentiality, an invitation to meaningful action, a conception that was successful, as we just saw.

However, there were also some failures, that sometimes did not allow participants to interact with INsono to its full potential. One of these failures was the idea of having a space in the center where children could sit and listen to the entire soundscape of the room. Although this was partially achieved, there were sounds that were not listened in this central spot, due to technical reasons that the musicians were not able to correct, despite their many efforts. At the same time, and although this central point (one of the "five little houses" has I called it before) was surrounded by glasses that aimed at protecting the space from sounds from the outside, this was also not totally achieved, and many times the soundscape of INsono was somehow contaminated by undesired sounds.

Even though, and as mentioned in the examples given above, there were many times where this idea of potentiality, of invitation to "enter a new world", was successful. One example rather interesting, besides those already mentioned in the lines above, happened in the beginning of the sound journey:

Children are standing in a line, waiting to enter the room where INsono is displayed. In absolute silence, two of the workshop leaders, without saying a single word, perform "an auditory body scan" to each child, using a handmade "stethoscope" created by them (Figure 5). The young explore smile, gazing their eyes in curiosity, opening their mouths like if wondering what is going to happen next. They are exited and thrilled by the beginning of the experience. They are ready to inhabit a new world and begin their exploratory journey (Field notes, February 15, 2017). 


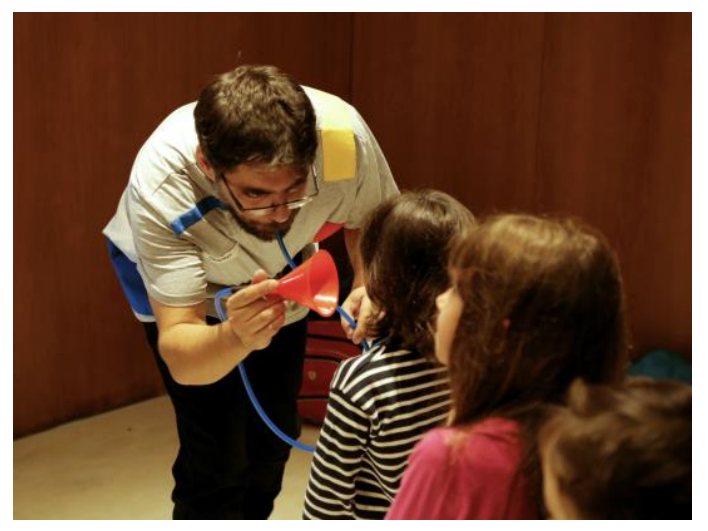

Figure 5. "The trampoline" - "Auditory body scan

When interviewing Madalena, she told me this is one of the key points of the challenge she usually makes to the artists that participate in this festival:

There is a moment that is created by the environment itself, and by what artists do, that I call 'the trampoline. It is a moment where nothing has to be said or explained. It is a moment when children immediately feel they will jump into another world.

Confronting stereotyped ideas of what is an educative artistic experience, Madalena also recognizes the importance of working using pedagogical strategies from non-formal contexts of learning, where educators do not usually feel the strict constraints of a classroom setting about what is and what is not "educative'. In this way, she calls for an education full of wonder, beauty and surprise, challenging what she names as "didactic approaches to teaching art and music". She identifies these approaches as those in which adults are so committed in explaining everything, in translating everything into "a language that children might understand", that they seem to forget to just "let the children go, to let them experiment and enjoy the moment".

\subsection{Children's perspectives and ideas on INsono}

\subsubsection{Children's voices: A sense of wonderment and surprise}

Today's group is bigger than the previous ones.... I see that due to this issue, the workshop leaders have decided to divide the group in half: children from one of the subgroups were given a red ribbon to put on their wrist, children from the other subgroup were given a blue ribbon. One of the workshop leaders, Henrique, also uses a blue ribbon. Another, Rodrigo, wears a red ribbon. Children immediately understand who to follow.... As usually they first make a line, entering one by one, in silence. Henrique and Rodrigo don't say a word ... Each child goes through the stethoscope, the "trampoline" as Madalena called it, and gets ready to begin the sound journey. The other two workshop leaders, Gustavo and Tiago, are already waiting for them, ready to guide them on their trip, in the midst of sounds and silences. The group that is with Gustavo (to which Henrique later joins) starts the journey in the gongs' structure. When compared to the height of these six-year-olds, the structure seems immense ...

@ Ana Luísa Veloso. The content of this article is the sole responsibility of the authors. The Revista Electrónica de LEEME and Universitat de València are not liable for any legal actions that may arise involving the article's content. Revista Electrónica de LEEME - Lista Electrónica Europea de Música en la Educación-. http://ojs.uv.es/index/php/LEEME/index ISSN: 1575-9563. Editores: Universidad de Valencia y Jesús Tejada. Visibilidad de esta revista: SCOPUS, Emerging Sources Citation Index (Clarivate), EBSCO, CINDOC (CSIC), Citefactor, COPAC, Dialnet, DICE (CSIC), DOAJ, e-revistas (CSIC), EBSCO Premier, ERIH+, Gale Cengage Learning, INRECS, IRESIE, LATINDEX, MIAR, OCLC Worldcat, RESH, REDIB, RILM Core Journals, SUDOC, ULRICHS. Esta revista es de acceso libre mediante licencia Creative Commons 4.0 CC by. Política de archivado: etiqueta verde SHERPA-ROMEO. 
Some of the kids play in the gongs while others pass through them, listening to their colleagues. They seem fascinated. Eyes wide open, sometimes an inevitable whisper to the colleague next door, each object a different sound! And there are so many objects! And there are so many sounds! "How is it possible?" I hear one of the children whispers. From there they go to the small shelters where a series of sound devices built by the musicians are installed; the devices are equipped with motion sensors, and therefore start to play when the children get close, and stop playing when they get afar. What a surprise! Some children call those colleagues who are still in the gongs, willing to share the experience. Meanwhile, the other group, the one with the red ribbons, spreads out between the sounds of the mirror and the wooden beds. There are smiles of excitement, the beds are vibrating! And when someone touches the mirror it makes very strange sounds, depending on the place and the way it is touched! At each step a new surprise, a new invitation to exploration. Strings, springs, small amplified objects, which children approach to hear the "micro sounds" as one child called them. The soundscape is built on everyone's interaction... (field Notes, February 16, 2017).

As soon as children entered the room where INsono was waiting for them, the first reaction was usually of great surprise. Looking back, I think I might say that it was precisely this sense of surprise, awe and deep curiosity that gave children the desire to explore everything, as much as it was possible during the 50 minutes' period of each visit. As we can see in some of their interventions throughout group interviews:

Table 1. INsono: Voices from children

\begin{tabular}{|c|c|c|}
\hline February 14 & February 15 & February 16 \\
\hline $\begin{array}{l}\text { "It was so cool! I really liked it! } \\
\text { How did you managed to make all } \\
\text { those devices?" } \\
\text { "I felt we were in a music room, } \\
\text { different from all the music rooms I } \\
\text { have already seen... It was... full of } \\
\text { surprises! } \\
\text { "Those sounds in the mirror! It was } \\
\text { amazing! They were so cute! We } \\
\text { touched... and then... there were } \\
\text { sounds that came from the mirror!" }\end{array}$ & $\begin{array}{l}\text { "I felt my self in silence and I was } \\
\text { very impressed because I had never } \\
\text { heard those sounds. I mean, the } \\
\text { sounds, the instruments, they were } \\
\text { very strange ... I really liked being } \\
\text { inside INsono because I was always } \\
\text { very curious" } \\
\text { "I learned to improvise! It's so } \\
\text { cool! And I also learned that there } \\
\text { are not only 'normal' instruments } \\
\text { like the guitar or the violin; there } \\
\text { are also instruments that are } \\
\text { different, and make other types of } \\
\text { sounds..." }\end{array}$ & $\begin{array}{l}\text { "I think this was.... It is more of a } \\
\text { sound experience, as when a person } \\
\text { makes a very small sound with } \\
\text { something that is not really used to } \\
\text { make sounds, like a lamp, and I } \\
\text { think it was a very cute } \\
\text { experience!" }\end{array}$ \\
\hline
\end{tabular}

Source: self-made

When asked about what they had liked the most in INsono, what had really left an impression on them, and what they had learnt, children focused mainly on moments of curiosity, enjoyment, surprise and wonder that they felt while traveling through INsono. These moments seem to have been mainly prompted by the affordances offered by the structure, that acted as a constant invitation to exploration, and by the suggestions made by the workshop leaders, either through gestures, facial expressions or through strategies such as the "trampoline". All this acted as what Woods, when talking about the educational potentiality of experimental music, named as "environment-as teacher approach" (2019, p.460) that emphasizes the role that the surrounding environment might take in the learning process (Murillo, Riaño \& Berbel-Gómez, 2019), moving the teacher a little bit more to the background of the learning landscape and

@ Ana Luísa Veloso. The content of this article is the sole responsibility of the authors. The Revista Electrónica de LEEME and Universitat de València are not liable for any legal actions that may arise involving the article's content. Revista Electrónica de LEEME - Lista Electrónica Europea de Música en la Educación-. http://ojs.uv.es/index/php/LEEME/index ISSN: 1575-9563. Editores: Universidad de Valencia y Jesús Tejada. Visibilidad de esta revista: SCOPUS, Emerging Sources Citation Index (Clarivate), EBSCO, CINDOC (CSIC), Citefactor, COPAC, Dialnet, DICE (CSIC), DOAJ, e-revistas (CSIC), EBSCO Premier, ERIH+, Gale Cengage Learning, INRECS, IRESIE, LATINDEX, MIAR, OCLC Worldcat, RESH, REDIB, RILM Core Journals, SUDOC, ULRICHS. Esta revista es de acceso libre mediante licencia Creative Commons 4.0 CC by. Política de archivado: etiqueta verde SHERPA-ROMEO. 


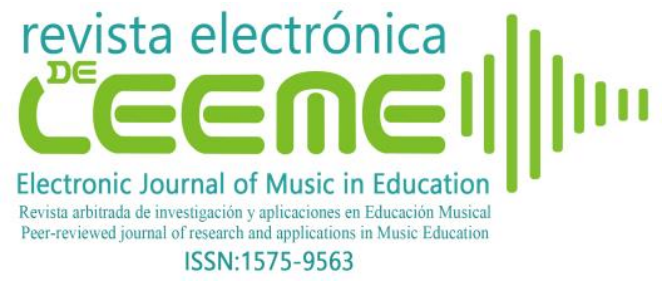

highlighting the participatory role that children might have in a rich and inviting environment. Resembling the strategies used in non-formal learning contexts, in this approach the teacher is not seen any more as the expert, the absolute knowledge holder, the one that controls all the processes involved in learning music. On the contrary, sharing responsibilities with her pupils, the teacher ensures, in this way, that they gain ownership of their musical participations and learning pathway; acting as a guide, she knows that one of her main tasks is to give learners a starting point to work from, assuring that participants feel safe enough in order to take risks and explore possibilities amidst the ambiguity of the moment (Folkestad, 2006; Hill, 2018; Tinkle, 2015; Wright \& Kanellopoulos, 2010). This aspect could, however, have been further explored. In the beginning, the workshop leaders intended to give children moments of total free exploration, alternating these moments with others, were children were guided by the workshop leaders. However, these "free moments" never actually happened These "free moments" ever actually happened, and the workshop leaders guided most of the moments when children were tracing their pathways through INsono. I think that the free moments were not possible mainly because the great surprise children felt when meeting INsono for the first time had the double role of motivating them deeply, but also of leaving them somehow a little bit lost, amazed with that huge structure, and without knowing exactly what to do. This could have been overcome if each group of children had had the opportunity to interact with INsono for a longer period. This by the way is, quite often, a flaw in this type of projects, and this is where school can have a major role in changing things for the better: continuing the work so that children don't feel that it was an experience where nothing will ever be repeated. It seems, therefore, that an effort must be made by teachers and principals to give continuity to these projects, so that the children evolve in their musical interactions (at the level of listening, performance and creation) with the sound material and new instruments in a growing understanding and complexity.

\subsubsection{Children's Voices: An immersion on sound}

Six-year-old children. Attentive to everything. Jumping from the trampoline into another world. In complete silence, allowing themselves to be guided by the workshop leaders. Eyes and ears wide open. The sound experience. Listening, touching sounds, feeling them in their bodies. Several sounds. Some kids are laying down on the wood beds, jumping a little bit with its vibrations; others are exploring the mirror, improvising for those listening next to the small speakers. They squat, sit, lie down in a participatory, interactive experience. I have no doubt that it is a quite meaningful listening experience. Why? Well, perhaps because of its multisensory dimension. Or perhaps because the experience is centered on a discovery process. Or perhaps because it awakens the senses and takes them on a flight through the imagination. A sound bath. An immersion on sound. As if sounds were water (field Notes, February 15, 2017).

Listening to children, we can see how the journey through INsono made them become deeply attentive to listening, and how they felt this "immersion on sound": 


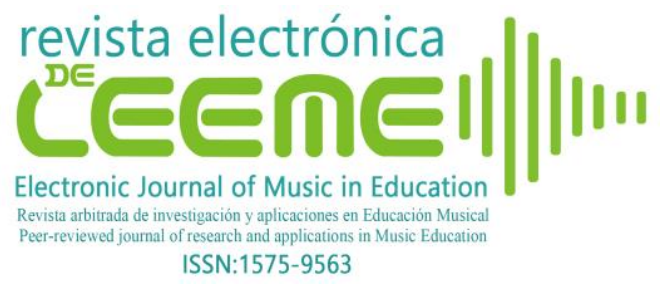

Ana Luísa Veloso

Rethinking experimental music within Music Education: Thoughts and feelings after a voyage through the Project INsono (Revista Electrónica de LEEME) Número 46, pp. 49-67 https://ojs.uv.es/index.php/LEEME/index

Table 2. INsono: Voices from children

\begin{tabular}{|c|c|c|}
\hline February 14 & February 15 & February 16 \\
\hline $\begin{array}{l}\text { "This music... It made me feel } \\
\text { sounds all over and inside my } \\
\text { body!" } \\
\text { "And I think what I liked the most } \\
\text { was listening, seeing and hearing } \\
\text { the sounds!" }\end{array}$ & $\begin{array}{l}\text { What I really liked were the sounds } \\
\text { from the bed, because they made } \\
\text { me jump!" } \\
\text { "Then I saw a sound. I saw the } \\
\text { sound beginning ... Then in the } \\
\text { glass... I felt it... I really liked it a } \\
\text { lot..." }\end{array}$ & $\begin{array}{l}\text { "What crossed my mind when I was } \\
\text { in the bed was that it seemed like I } \\
\text { was in a dream. And when it made } \\
\text { that noise it gave me... I felt like I } \\
\text { was inside... Inside the dream, } \\
\text { inside my brain!" }\end{array}$ \\
\hline $\begin{array}{l}\text { "It was so good because we could } \\
\text { pass through the gongs and hear my } \\
\text { colleagues playing on them. And } \\
\text { make music with my nails on the } \\
\text { strings, and I was also sitting on a } \\
\text { stool listening to music with my } \\
\text { colleagues" }\end{array}$ & $\begin{array}{l}\text { "What really called my attention } \\
\text { was that when we make silence, we } \\
\text { can really listen to different } \\
\text { sounds..." }\end{array}$ & $\begin{array}{l}\text { "What I liked most was going } \\
\text { through the middle of the metal } \\
\text { plates that had red balls attached to } \\
\text { them... We grabbed the balls and } \\
\text { pulled them back and when pulling } \\
\text { and letting go there was a } \\
\text { wonderful sound ...." }\end{array}$ \\
\hline
\end{tabular}

\section{Source: self-made}

These ideas clearly evoke what Ceraso $(2018$, p.6) named as "multimodal listening" a concept that the author defines in the following way:

Multimodal listening moves away from ear-centric approaches to sonic engagement and, instead, treats sonic experience as holistic and immersive. Unlike practices in which the listener's primary goal is to hear and interpret audible sound, multimodal listening accounts for the ecological relationship among sound, bodies, environments, and materials (idem, pp.67).

INsono, as a site for multisensory/multimodal listening, prompts meaning from the very ways that sounds touch, embrace and penetrate listeners, rising clearly from a position that acknowledges the bodily roots of all music experience and envisages listening as a single global phenomenon that involves body mind and context (Veloso, 2017; Veloso, Teixeira \& Bessa, 2019).

In part, this was achieved by the affordances created by the different devices and tools used in INsono - headphones connected to different sound materials, resonant platforms, amplified sounding objects, IPads, electromagnetic sound sources, acoustic automatons, or movement sensors - that somehow transformed INsono in a truly active, participatory experience. This, however, also had a reverse side on the experience of INsono. Immersed in their interactions with the sound installation/collective musical instrument, the intention of children playing together, making music in a collaborative way, ended up being a little bit forgotten. Once again, I think that more time would need for the children to become familiar with INsono, to explore it in depth, so that this aspect could be further worked on. It is not that it did not happen. On the contrary. Often it was possible to observe the children interacting with each other, playing together, or creating something for each other to listen to. It just happens that this process was not as rich as expected. Therefore, it is now clear to the musicians that this aspect will have to be rethought in future presentations of INsono.

@ Ana Luísa Veloso. The content of this article is the sole responsibility of the authors. The Revista Electrónica de LEEME and Universitat de València are not liable for any legal actions that may arise involving the article's content. Revista Electrónica de LEEME - Lista Electrónica Europea de Música en la Educación-, http://ojs.uv.es/index/php/LEEME/index ISSN: 1575-9563. Editores: Universidad de Valencia y Jesús Tejada. Visibilidad de esta revista: SCOPUS, Emerging Sources Citation Index (Clarivate), EBSCO, CINDOC (CSIC), Citefactor, COPAC, Dialnet, DICE (CSIC), DOAJ, e-revistas (CSIC), EBSCO Premier, ERIH+, Gale Cengage Learning, INRECS, IRESIE, LATINDEX, MIAR, OCLC Worldcat, RESH, REDIB, RILM Core Journals, SUDOC, ULRICHS. Esta revista es de acceso libre mediante licencia Creative Commons 4.0 CC by. Política de archivado: etiqueta verde SHERPA-ROMEO. 


\section{Rethinking music education: a new look through experimental music}

As a sound installation/sound route, INsono clearly achieved the educational and musical goals initially thought and proposed by the musicians and Madalena Wallenstein. Still, some things can be improved in a similar following experience, as already observed before. This is specially truth when we think about INsono as a collective musical instrument, something that was not fully achieved and that needs to be overcome in future presentations or similar projects. Nevertheless, the analysis of the processes involved in this specific experience with INsono calls for a series of ideas that seem now worthy to explore, in order to rethink some of the aspects related to the specificities of experimental music and its inclusion in educational contexts.

First and doubtlessly, INsono, being based on concepts and practices connected to experimental music, challenges the very idea of 'music', and of what is considered to be 'musical', and to make music with children: It does so by, on the one side, defying those educative practices that infantilize the notion of "music for children", narrowing it's sense to a set of prescribed and somehow "childish" ways of interacting with sounds, and where children are at risk of losing their space of intervention and participation. And, on the other side, by presenting highly democratic and inclusive ideas, not only because this project seeks to embrace a vast and multiple sound pallet, but also because it stands for the belief that all genres and styles of music are suitable for children.

Second, and in general, those children that visited and explored INsono gave a particularly good response to the challenges posed by the structure and the workshop leaders. However, we cannot forget that, as explained before, the visits were made specially from children whose teachers and schools have already a special concern with artistic education and in providing their pupils creative and innovative experiences in this area. It is therefore extremely important to mention that these projects should be spread across a diversity of schools, with different socio-cultural backgrounds. This type of activities can in no way be limited to a small number of privileged children that attend schools that have a special sensitivity for these issues. It is therefore especially important that music teachers become familiar with these languages and tools, so that all children can have access to them.

Third, what has been said so far might also help us to reflect on the issue of using experimental music - as listening, performing, and creating - within the classroom context. The claims made by Green (2008) are quite appropriate as, in fact, it's expectable that experimental music - being so distant from what is the daily musical lives of children - might indeed provoke in pupils a sense of detachment and disinterest, leading to possible modes of "alienation". However, and as it was observed when analyzing the field notes and children's' interviews, INsono brought a valuable and meaningful moments for participants specially because of its capacity to promote a sense of surprise, curiosity or absence of "fear of failure" Nonetheless,

@ Ana Luísa Veloso. The content of this article is the sole responsibility of the authors. The Revista Electrónica de LEEME and Universitat de València are not liable for any legal actions that may arise involving the article's content. Revista Electrónica de LEEME - Lista Electrónica Europea de Música en la Educación-. http://ojs.uv.es/index/php/LEEME/index ISSN: 1575-9563. Editores: Universidad de Valencia y Jesús Tejada. Visibilidad de esta revista: SCOPUS, Emerging Sources Citation Index (Clarivate), EBSCO, CINDOC (CSIC), Citefactor, COPAC, Dialnet, DICE (CSIC), DOAJ, e-revistas (CSIC), EBSCO Premier, ERIH+, Gale Cengage Learning, INRECS, IRESIE, LATINDEX, MIAR, OCLC Worldcat, RESH, REDIB, RILM Core Journals, SUDOC, ULRICHS. Esta revista es de acceso libre mediante licencia Creative Commons 4.0 CC by. Política de archivado: etiqueta verde SHERPA-ROMEO. 
there is a critical issue here. Each child got involved with INsono for a period of 50 minutes only. We may well wonder if this is sufficient to take definitive conclusions about the role that experimental music and projects like INsono might have in a classroom context. In my perspective this is not enough, and to envisage educational projects within experimental music, we have to go beyond these moments of surprise and curiosity, planning and offering children growing challenges that will make them feel that they are creating something special, pursuing a path that will evolve in time, both individually and collectively. In this sense, educational projects like INsono should - both within formal and non-formal settings - in the future, be planned across larger periods of time, in order to promote this sense of a practice that grows in complexity, while, at the same time, pupils gain familiarity and new ways of thinking and doing within the field of experimental music.

Finally, the activities offered by the ways INsono was explored are based on a series of attitudes that can be of extreme importance in the personal growth of each child: in this project, while children were interacting with INsono, they were highly encouraged to have an exploratory attitude where the "fear to fail" was clearly diminished and where there was no authority dictating what was, in musical terms, right or wrong; workshop leaders focused their interactions mainly on gestures and facial expressions in the absence of words that challenged children to make music with the objects that surrounded them. Using similar strategies in other contexts, such as a classroom or an ensemble, might become a platform for the development of new ways of being and thinking that increase the value of using experimental music with children.

As a final note, I would like to refer that in no way do I make an apology here that everything within music education should derive from experimental music. In this matter, I echo Paynter and Aston's words: "the creative experiment is only one small part of music in education: but we believe it is a very important part and one that should not be neglected" (1 970, p.23). I stand, therefore, on the one hand, for an approach based on the diversity of music(s) that exist throughout the world and that includes experimental music, rock, or jazz, and, on the other, also based on the diverse ways through which human beings make music, from ancient times until today, be it through vocal or instrumental performance, free improvisations, idiomatic improvisation, music composition and many others.

Only in this way, I believe, can we have a music education that promotes a real openness to the diversity and multiplicity of factors that influence the ways children might feel motivated to engage and take ownership of the music in which they are invited to participate.

\section{References}

Barrett, M.S. \& Stauffer, S.L. (2009). Narrative Inquiry: From Story to Method. In M.S. Barrett \& S.L. Stauffer (Eds.), Narrative Inquiry in Music Education (pp.7-17). doi:10.1007/978-1-4020-9862-8_2 
Barrett, M.S. \& Stauffer, S.L. (2012). Resonant Work: Toward an Ethic of Narrative Research. In M.S. Barrett \& S.L. Stauffer (Eds.), Narrative Soundings: An Anthology of Narrative Inquiry in Music Education (pp.1-17). doi:10.1007/978-94-007-0699-6_1

Bowman, W. (2002). Educating Musically. In R. Colwell \& C. Richardson (Eds.), The New Handbook of Research in Music Teaching and Learning (p. 63-84). New York: Oxford University Press.

Bowman, W. (2006). Why Narrative? Why Now? Research Studies in Music Education, 27(1), 5-20. doi:10.1177/1321103X060270010101

Bowman, W. (2009). Charting Narrative Territory. In M.S. Barrett \& S.L. Stauffer (Eds.), Narrative Inquiry in Music Education (pp. 211-222). doi:10.1007/978-1-4020-98628_20

Bruner, J. (1990). Acts of meaning. London: Harvard University Press.

Bruner, J. (1996). The Culture of Education. Cambridge, MA: Harvard University Press

Cage, J. (1994). Silence (New edition edition). London: Marion Boyars.

Ceraso, S. (2018). Sounding Composition: Multimodal Pedagogies for Embodied Listening. Pittsburgh, Pa: University of Pittsburgh Press.

Clandinin, D.J. (2013). Engaging in Narrative Inquiry. Walnut Creek, California: Routledge.

Finney, J. (2011a). Music Education in England, 1950-2010: The Child-Centred Progressive Tradition. Farnham, UK: Ashgate.

Finney, J. (2011b). John Paynter, music education and the creativity of coincidence. British Journal of Music Education, 28(01), 11-26. doi:10.1017/S0265051710000343

Flick, U. (2014). An Introduction to Qualitative Research. London, UK: SAGE.

Folkestad, G. (2005). The Local and the Global in Musical Learning: Considering the Interaction Between Formal and Informal Settings. In Cultural diversity in music education (pp. 23-28). Brisbaine, AU: Australian Academic Press.

Gibson, J.J. (2014). The Ecological Approach to Visual Perception. New York: Routledge.

Green, L. (2008). Music, informal learning and the school: A new classroom pedagogy. Hampshire, UK: Ashgate Publishing, Ltd.

Hill, S.C. (2018). A "Sound" Approach: John Cage and Music Education. Philosophy of Music Education Review, 26(1), 46-62. doi:10.2979/philmusieducrevi.26.1.04

@ Ana Luísa Veloso. The content of this article is the sole responsibility of the authors. The Revista Electrónica de LEEME and Universitat de València are not liable for any legal actions that may arise involving the article's content. Revista Electrónica de LEEME - Lista Electrónica Europea de Música en la Educación-. http://ojs.uv.es/index/php/LEEME/index ISSN: 1575-9563. Editores: Universidad de Valencia y Jesús Tejada. Visibilidad de esta revista: SCOPUS, Emerging Sources Citation Index (Clarivate), EBSCO, CINDOC (CSIC), Citefactor, COPAC, Dialnet, DICE (CSIC), DOAJ, e-revistas (CSIC), EBSCO Premier, ERIH+, Gale Cengage Learning, INRECS, IRESIE, LATINDEX, MIAR, OCLC Worldcat, RESH, REDIB, RILM Core Journals, SUDOC, ULRICHS. Esta revista es de acceso libre mediante licencia Creative Commons $4.0 \mathrm{CC}$ by. Política de archivado: etiqueta verde SHERPA-ROMEO. 
Holmes, T. (2008). Electronic and Experimental Music: Technology, Music, and Culture. New York: Routledge.

Kerchner, J.L. (2014). Music across the Senses. New York: Oxford University Press.

Mota, G. (2020). Six Young Women on a Band-Stand: Voices Lost in Time. In T.D. Smith \& K.S. Hendricks (Eds.), Narratives and Reflections in Music Education: Listening to Voices Seldom Heard (pp.19-32). Cham: Springer. doi: 10.1007/978-3-030-28707-8_2

Murillo, A., Riaño, M. E., Berbel-Gómez, N. (2019) The Classroom as a Sounding Board for Sonorous Creation: New Architectures and Technological Tools to Bring the Art of Sound to Education. Revista Electrónica de LEEME, 1(43), 6-18. doi:10.7203/LEEME.43.14007

Nyman, M. (1999). Experimental Music: Cage and Beyond. Cambridge, UK: Cambridge University Press.

Paynter, J. \& Aston, P. (1970). Sound and silence: Classroom projects in creative music. Cambridge: Cambridge University Press.

Reybrouck, M. (2012). Musical Sense-Making and the Concept of Affordance: An Ecosemiotic and Experiential Approach. Biosemiotics, 5(3), 391-409. doi:10.1007/s12304-012-91446

Saldana, J. (2009). The Coding Manual for Qualitative Researchers. London, UK: SAGE.

Stake, R. (2008). Qualitative Case Studies. In N. Denzin \& L. Yvona (Eds.), Strategies of Qualitative Inquiry (pp. 119-149). Thousand Oakes, CA: MENC.

Tenney, J. (2015). Darmstadt Lecture 1990. In L. Polansky (Ed.), From Scratch: Collected Writings (pp. 350-367). Urbana: University of Illinois Press.

Tinkle, A. (2015). Experimental Music with Young Novices: Politics and Pedagogy. Leonardo Music Journal, 25, 30-33. doi:10.1162/LMJ_a_00930

Veloso, A.L. (2017). Composing music, developing dialogues: An enactive perspective on children's collaborative creativity. British Journal of Music Education, 34(3), 259-276. doi:10.1017/S0265051717000055

Veloso, A.L., Ferreira, A.I. \& Bessa, R. (2019). Adapting a Music Listening App to Engage Pupils in Personal and Social Development: A Case Study. Bulletin of the Council for Research in Music Education, 220, 63-83. Retrived from: https://www.jstor.org/stable/10.5406/bulcouresmusedu.220.0063?seq=1

@ Ana Luísa Veloso. The content of this article is the sole responsibility of the authors. The Revista Electrónica de LEEME and Universitat de València are not liable for any legal actions that may arise involving the article's content. Revista Electrónica de LEEME - Lista Electrónica Europea de Música en la Educación-. http://ojs.uv.es/index/php/LEEME/index ISSN: 1575-9563. Editores: Universidad de Valencia y Jesús Tejada. Visibilidad de esta revista: SCOPUS, Emerging Sources Citation Index (Clarivate), EBSCO, CINDOC (CSIC), Citefactor, COPAC, Dialnet, DICE (CSIC), DOAJ, e-revistas (CSIC), EBSCO Premier, ERIH+, Gale Cengage Learning, INRECS, IRESIE, LATINDEX, MIAR, OCLC Worldcat, RESH, REDIB, RILM Core Journals, SUDOC, ULRICHS. Esta revista es de acceso libre mediante licencia Creative Commons 4.0 CC by. Política de archivado: etiqueta verde SHERPA-ROMEO. 
Windsor, W.L. \& de Bézenac, C. (2012). Music and affordances. Musicae Scientiae, 16(1), $102-$ 120. doi: $10.1177 / 1029864911435734$

Woods, P.J. (2019). Conceptions of teaching in and through noise: A study of experimental musicians' beliefs. Music Education Research, 21(4), 459-468. doi:10.1080/14613808.2019.1611753

Wright, R. \& Kanellopoulos, P. (2010). Informal music learning, improvisation and teacher education. British Journal of Music Education, 27(01), 71-87. doi:10.1017/S0265051709990210 